Revista de Journal of Integrated

GESTÃO COSTEIRA Integrada COSTAL ZONE MANAGEMENT

\title{
The influence of the river runoff in the artisanal fisheries catches in tropical coastal waters - The case of the Zambezi River and the fisheries catches in the northern Sofala Bank, Mozambique*
}

\author{
Antonio Mubango Hoguane ${ }^{\circledR}$, a $;$ Elisa Vasco Armando ${ }^{\mathrm{b}}$
}

\begin{abstract}
The artisanal catches contributes significantly in the overall annual fish production in Mozambique, estimated to 115,000 140,000 tones, and thus of significant importance to livelihood of the coastal communities. However, the variation in fish production depends on several factors, among which the climatic factors, that need to be understood for sustainable fisheries management. The present study analyses the influence of the river runoff in coastal fisheries production, using the Zambezi Runoff (1996-2014) as a climatic indicator and the artisanal fisheries catches (2000-2014) as the indicator of fisheries production. The results obtained indicated that the artisanal catches in Sofala Bank were dominated by resident species in the region of fresh water influence (Engraulidae (53\%), Clupeídea (10\%), Sciaenidae (8\%) and Sergestidae (7\%)), by species that inhabit these regions at their earlier stage of life (Penaeidae (4\%)) and by species that inhabit the vicinity and move to the region of fresh water influence for feeding (Trichiuridae (6\%), Ariidae (4\%), Carangidae (4\%) and Hemulidae (2\%)); The total annual catches were positively-linearly correlated with the total annual runoff (slope $=0.343, \mathrm{r}^{2}=0.500, \mathrm{p}=0.005, \mathrm{n}=14$ ). Further, the catches correlated better with both the wet season runoff (slope $=0.534, \mathrm{r}^{2}=0.369, \mathrm{p}=0.021, \mathrm{n}=14$ ) and the dry season runoff ( slope $=0.773, \mathrm{r}^{2}=0.389, \mathrm{p}=0.013, \mathrm{n}=15$ ). The result is justified by the fact that most of the species caught (Engraulidae, Clupeídea, Sergestidae and Penaeidae) live in the region of freshwater influence, with one to two years life span and recruited to fisheries within the first year of their life. The present study emphasises the importance of the environmental/climatic factors such as river runoff in the fish production, and hence, on the need for the inclusion of the runoff variability in the fisheries management strategies.
\end{abstract}

Keywords: River runoff, climatic factors, fisheries production, sustainable fisheries.

\section{RESUMO}

Influência do escoamento de rios nas capturas de pescarias artesanais nas águas costeiras tropicais - o caso do Rio Zambeze e as capturas na zona norte do Banco de Sofala, Moçambique

As pescarias artesanais contribuem de uma forma significativa na produção pesqueira total de Moçambique, estimada em cerca de 115000 -140 000 toneladas por ano, e por isso com impacto positivo na economia das comunidades costeiras. No entanto, a variação da produção pesqueira depende de muitos fatores, de entre eles os fatores climáticos, que devem ser com-

\footnotetext{
${ }^{\circledR}$ Corresponding author to whom correspondence should be addressed.

${ }^{\mathrm{a}}$ School of Marine and Coastal Sciences, Eduardo Mondlane University, PO Box 128, Quelimane, Mozambique. e-mail: $<$ hoguane@yahoo.com.br>.

b Ministry of Science and Technology, Zambézia Office. e-mail: <elisarmando@ymail.com>.
}

* Submission: 27 MAR 2015; Peer review: 24 APR 2015; Revised: 8 MAY 2015; Accepted: 2 JUN 2015; Available on-line: 29 JUN 2015
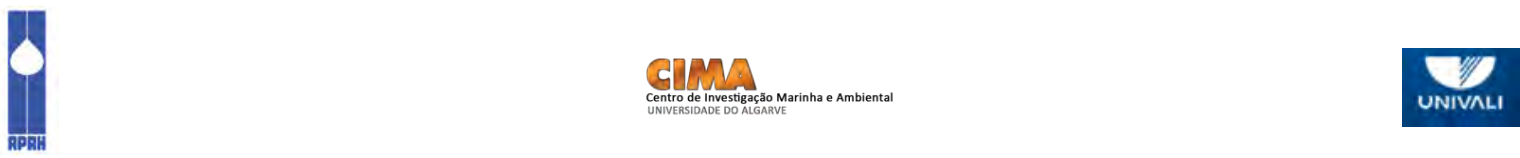
preendidos para uma gestão sustentável das pescarias. No presente trabalho analisou-se a influência da descarga dos rios na produção pesqueira tomando como base o escoamento do Rio Zambeze (1996-2014), como variável climática e as capturas dos pescadores artesanais no Banco de Sofala (2000-2014), como indicador da produção pesqueira. Os resultados indicaram que a composição especifica das capturas artesanais no Banco de Sofala eram dominadas por espécies residentes nas zonas de influência de água doce (Engraulidae (53\%), Clupeídea (10\%), Sciaenidae (8\%) e Sergestidae (7\%)), por espécies que passam a parte inicial de sua vida em zonas de influência de água doce (Penaeidae (4\%)) e por espécies que habitam na vizinhança de zonas de influencia de água doce e que se deslocam para estas zonas para se alimentar (Trichiuridae (6\%), Ariidae (4\%), Carangidae (4\%) e Hemulidae (2\%)); as capturas correlacionaram-se positivamente e significativamente com o escoamento total anual (tangente $=0,343, r^{2}=0,500, p=0,005, n=14$ ). As capturas correlacionaram se bem tanto com escoamento da época chuvosa (tangente $=0,534, r 2=0,369, p=0,021, n=14$ ) como com escoamento da época seca (tangente $=0,773, r 2=0,389, p=0,013, n=15)$. Este resultado se justifica pelo facto de a maioria das espécies nas capturas (Engraulidae, Clupeídea, Sergestidae e Penaeidae) habitarem zonas de influencia de água doce, com um ciclo de vida de um a dois anos, e serem recrutados para a pesca dentro do seu primeiro ano de vida. O presente estudo enfatiza a importância dos fatores ambientais/climáticos tais como escoamento dos rios na produção pesqueira e dai a necessidade de sua inclusão nas estratégias de gestão das pescarias.

Palavras-chave: Escoamento do rio, fatores climáticos, produção pesqueira, gestão sustentável das pescarias.

\section{Introduction}

Mozambican coastal waters are rich in fisheries and species diversity (Hoguane \& Pereira, 2003). The total annual artisanal fisheries catches in tones were 65,535 , $83,058,104,069,82,607$ and 132,238 for the years 2007, 2008, 2009, 2010 and 2011, respectively (IIP annual reports). The artisanal fisheries catches contribute on average with about $87 \%$ of the total annual catch, as recorded in fish landings (Jacquet \& Zeller, 2007). Most of the artisanal catches are directed to local market, and contribute significantly to the livelihood of the coastal communities and to local economy.

The relatively high productivity in coastal waters is mostly attributed to land based nutrients input into the coastal waters through the river or coastal rainfall leaching (Hoguane et al., 2012), hence, the positive correlation between the river runoff and the coastal catches. There are several studies conducted relating the coastal productivity and river runoff. Loneragan (1999), studied the influence of the river runoff in coastal ecosystems in Queensland, Australia, and concluded that the higher the runoff the higher the production of commercial and recreational fish species. Maynecke et al. (2006) examined the relationship between the coastal freshwater runoff and the fisheries production, in same place, and found that $30 \%$ of the total variability in catch could be explained by freshwater flow into coastal waters. Conway et al. (2005) investigated the inclusion of the river runoff in the management of the natural resources, including inland waters, in East Africa, and discussed the complex interaction between climate, environment and social issues and reiterated the need to consider the runoff variability in the management of the natural resources. The scientific reasons of the positive relationship, often empirical, observed between the river runoff and the coastal fisheries reside in the fact that the river runoff and coastal water drain sediments and nutrients to the coastal waters, which in turn establish an appropriate shelter for the development of the larvae and juveniles and fertilize the coastal water for phytoplankton production, the foothold of the entire marine food web (Gammelsrød, 1992; Meynecke et al., 2006; Ayub, 2010).

In Mozambique, most of the studies conducted related to fisheries are mainly directed to surveys and stock assessment, and there are seldom studies relating the environmental issues and fisheries' production. Gammelsrød (1992) studied the effect of Zambezi Runoff and the shallow water shrimp production in Sofala Bank, and observed a positive correlation between the runoff and the shrimp catch; Hoguane et al. (2012) studied the relationship between the coastal rainfall and the artisanal catches in the northern Mozambique, and observed that the rainfall has a positive effect on coastal fisheries production.

According to Larkin (1996), further sustained by Garcia et al. (2003), the fisheries management measures should take into account the environmental factors such as river runoff. The present study examines the relationship between the Zambezi River, the largest river in Southern Africa, and one of the largest rivers in Africa, and the artisanal fisheries production in Sofala Bank. Considering the fact that the river is dammed, with two major hydroelectric dams, the Kariba dam in Zimbabwe and the Cabora Bassa dam, in Mozambique, the question remains whether the river is still tuned with ecological seasonal cycles.

\section{Description of the study area}

The Sofala Bank, with about $15,169 \mathrm{~km}^{2}$ and $75 \mathrm{~m}$ average depth, located in between the Latitudes $16^{\circ} 05^{\prime} \mathrm{S}$ and $21^{\circ} 00^{\prime} \mathrm{S}$, is the largest shelf in Eastern African coast (Figure 1) and the major fisheries zone in Mozambique (Gammelsød, 1992). The climate is subtropical humid with two distinct seasons: the summer or rainy season and the winter or dry season. 


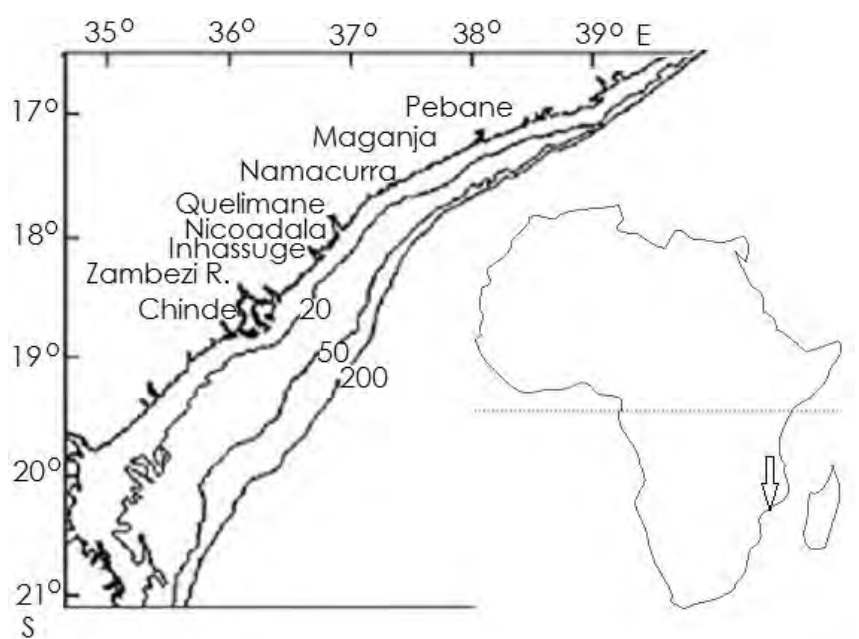

Figure 1 - Study area. Location map of the study area.

Figura 1 - Área de estudo. Mapa de localização da área de estudo.

The average air temperature varies between 24 and $29^{\circ} \mathrm{C}$; the dominant winds are SE-trade. The tides are semi-diurnal with amplitudes of 0.4 to $4.5 \mathrm{~m}$ during the neap and spring tides, respectively. The shelf receives freshwater water from several rivers; being the Zambezi River the major, which discharge on average about $3,000 \mathrm{~m}^{3} \mathrm{~s}^{-1}$, dominating the water masses in the Sofala Bank, consequently the water salinity in coastal waters, varies on average from 32 to 35 , and could drop further during the rainy season (Gammelsrød, 1992). The width of the Zambezi plume, as described by Siddorn et al. (2001) and modelled by Nehama \& Reason (in press), varies from 30 to 50 nautical miles, being wider nearest the delta, and its length is about 160 nautical miles, from the delta northwards (Figure 2).

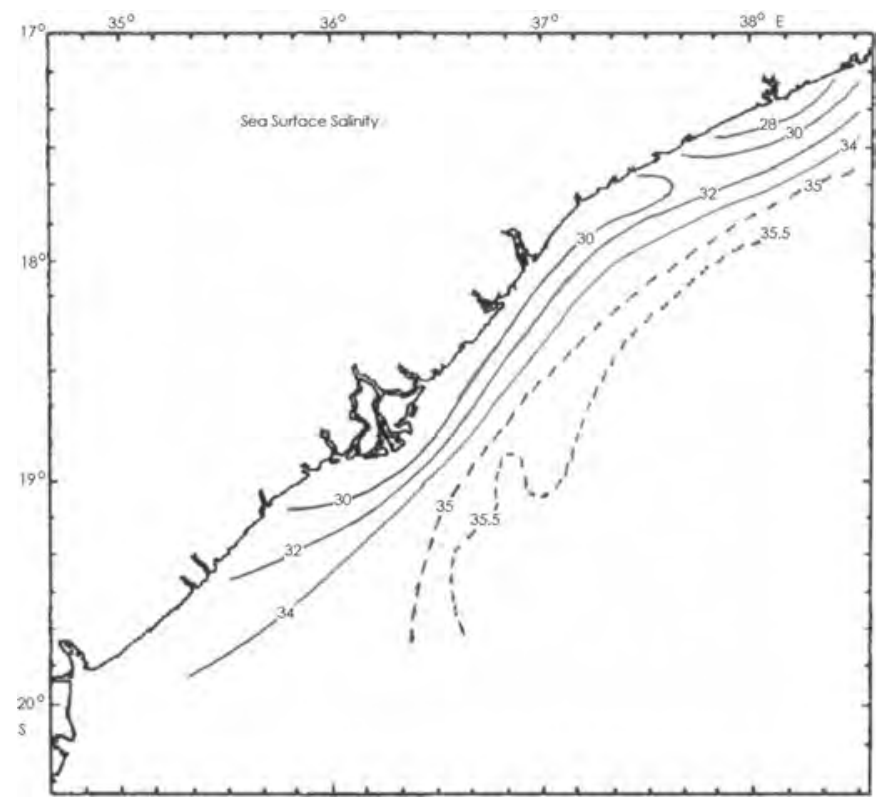

Figure 2 - Sea surface salinity distribution in Sofala Bank (Siddorn et al., 2001)

Figura 2 - Distribuição de salinidade de superficie no Banco de Sofala (Siddorn et al., 2001).

Table 1 - Annual artisanal catches (tons), from beach seine, recorded at the fish landings in coastal districts of Zambézia Province, northern Sofala Bank, during the period 2000-2014.

Tabela 1 - Capturas anuais (toneladas) de pescadores artesanais, através de arrasto à praia, registadas nos distritos costeiros da Província de Zambézia, zona norte do Banco de Sofala, durante o período 2000-2014.

\begin{tabular}{|c|c|c|c|c|c|c|c|c|}
\hline Year & Pebane & Maganja & Namacurra & Nicoadala & Quelimane & Inhassunge & Chinde & Total \\
\hline 2000 & 16,894 & 5,561 & 648 & 2,487 & 682 & - & - & 26,272 \\
\hline 2001 & 19,292 & 2,553 & 1,129 & 3,604 & 671 & - & - & 27,249 \\
\hline 2002 & 11,739 & 5,755 & 1,036 & 3,246 & 477 & - & - & 22,253 \\
\hline 2003 & 12,251 & 3,692 & 944 & 2,013 & 483 & - & - & 19,383 \\
\hline 2004 & 11,905 & 4,043 & 1,161 & 2,649 & 831 & - & - & 20,589 \\
\hline 2005 & 12,366 & 3,329 & 1,471 & 1,388 & 850 & 915 & 433 & 20,752 \\
\hline 2006 & 20,228 & 4,301 & 1,102 & 1,307 & 1,207 & 998 & 632 & 29,774 \\
\hline 2007 & 15,377 & 4,832 & 1,022 & 4,618 & 2,543 & 873 & 892 & 30,157 \\
\hline 2008 & 14,099 & 4.166 & 2,006 & 5,664 & 4,295 & 1,678 & 564 & 30,473 \\
\hline 2009 & 12,682 & 4,412 & 451 & 4,002 & 955 & 1,813 & 795 & 25,110 \\
\hline 2010 & 7,453 & 3,224 & 690 & 1,431 & 238 & 1,140 & 807 & 14,983 \\
\hline 2011 & 6,158 & 3,220 & 673 & 2,534 & 1,061 & 1,426 & 1,300 & 16,372 \\
\hline 2012 & 7,503 & 1,968 & 635 & 1,541 & 1,984 & 904 & 732 & 15,267 \\
\hline 2013 & 11,715 & 2,583 & 669 & 2,210 & 1,918 & 1,288 & 1,273 & 21,656 \\
\hline 2014 & 10,066 & 2,978 & 1,009 & 1,639 & 1,856 & 1,055 & 1,264 & 19,867 \\
\hline Total & 189,728 & 56,617 & 14,646 & 40,332 & 20,051 & 12,089 & 8,693 & 342,156 \\
\hline
\end{tabular}




\section{Data}

The present study was based in monthly artisanal catch landing data, from the beach seine, undertaken in seven coastal districts of the Zambézia Province, namely, Pebane, Maganja da Costa, Namacurra, Nicoadala, Quelimane, Inhassunge and Chinde, located in the northern Sofala Bank, during the period 2000 - 2014 (Table 1), and the monthly Zambezi River runoff as measured in Station E-320, located in Tete Province, about $400 \mathrm{~km}$ upstream from mouth, during the period 1997 to 2014.

The year 2001 recorded extreme high runoff, during the wet season, and so considered abnormal, and consequently removed from the analysis. However, the dry season runoff of 2001 was considered. The catch data was kindly provided by the Institute for Fisheries Research (IIP), Zambézia Office, and the Zambezi River runoff data was kindly provided by The Zambezi River Basin Administration (ARA-Zambezi). The catch data was collected by samplers in each fishing centre, three days a week. During the sampling period a number of boats and of fishing gears used in the day was recorded and a random sample of 10 percent of the catch was selected for fish composition and biometric data analysis.

The overall monthly catch in a fishing centre was estimated considering the average daily catch and average number of boats and of active fishing gears recorded during the sampling periods, and 21 days, an average number of fishing days a month, based on the census carried by IDPPE in 2004. Since the recorded fishing effort of the artisanal fisheries, based on days of fishing, does not capture adequately the effort the total annual catch was then used as an indication of the fisheries production, as indicated by Hoguane et al. (2012). Hence, the total annual catch of the artisanal fisheries was correlated with the annual river discharge and then, sequentially, with the wet or rainy and dry seasons' runoffs, using a statistical package MINITAB.

\section{Result and discussion}

Figure 3 presents the Zambezi runoff, the total annual runoff (October-September), the rainy or wet season runoff (October-March) and the dry season runoff (May-August), measured in Tete Hydrological Station E-320, during the period from the hydrological year $1996 / 97$ to $2010 / 14$. The total annual Zambezi runoff varied from 41,000 to $84,000 \mathrm{Mm}^{3}$, observed in the hydrological year 1996/97 and 2009/10, respectively; the wet season runoff varied from 26,000 and $46,000 \mathrm{Mm}^{3}$, recorded in the hydrological years 1996/97 and $2007 / 08$, respectively and the dry season runoff varied from 12,000 and $32,000 \mathrm{Mm}^{3}$ observed in the years 1997 and 2011, respectively.

Figure 4 presents the time series of the annual (Jan. Dec.) artisanal annual catches, by the beach seine, recorded in Sofala Bank, during the period 2000 to 2014. The lowest catch was 20,000 tonnes observed in 2003 and the highest was 35,000 tonnes observed in 2010 . The period between 2003 and 2005 was characterized by low catches and the period 2006 to 2010 was characterised by relatively high catches, with a minor reduction in 2009. Table 2 presents the dominant species in the artisanal catch in Sofala Bank as recorded during the period 2000 to 2014. The most dominant family species were Engraulidae with $53 \%$, followed by Clu-

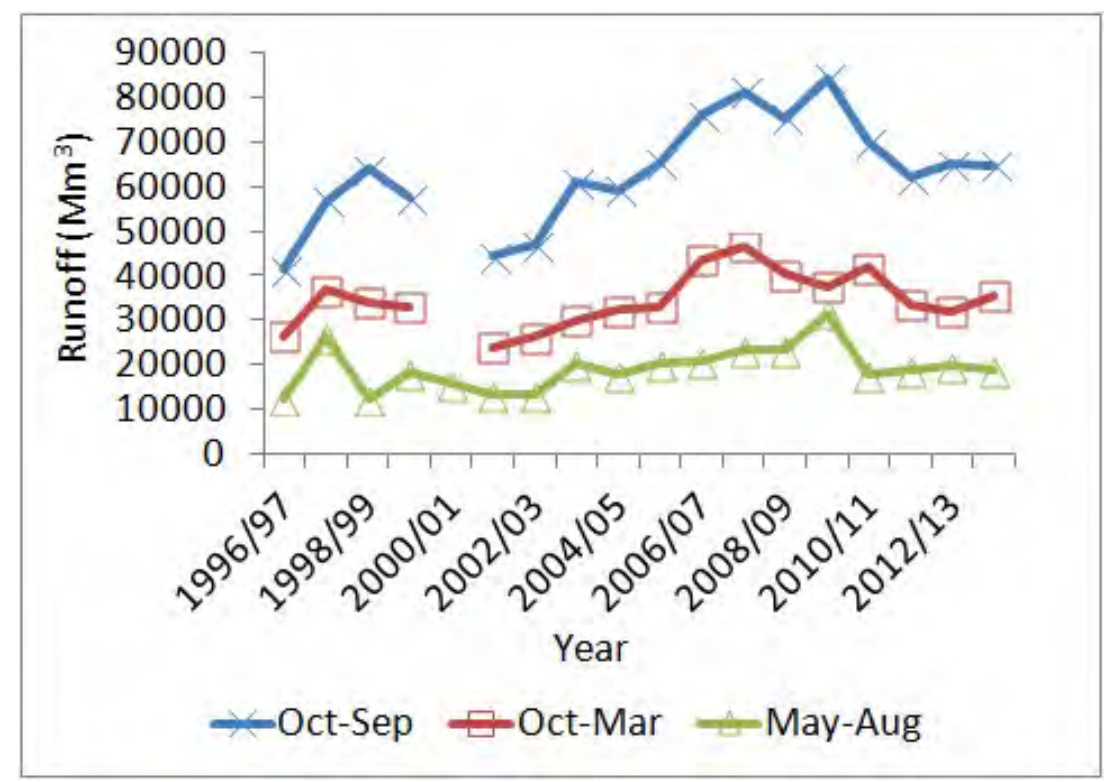

Figure 3 - Time series of the Zambezi total annual runoff (Oct.-Sep.), dry season runoff (Oct.-Mar.) and dry season runoff (May-Aug.), measured in Tete Hydrological Station E-320.

Figura 3 - Serie temporal do escoamento do Rio Zambeze total anual (Out.-Set.), do período húmido ou chuvoso (Out.-Mar.) e do período seco (Maio-Ago.), medido na Estacão Hidrológica de Tete E-320. 


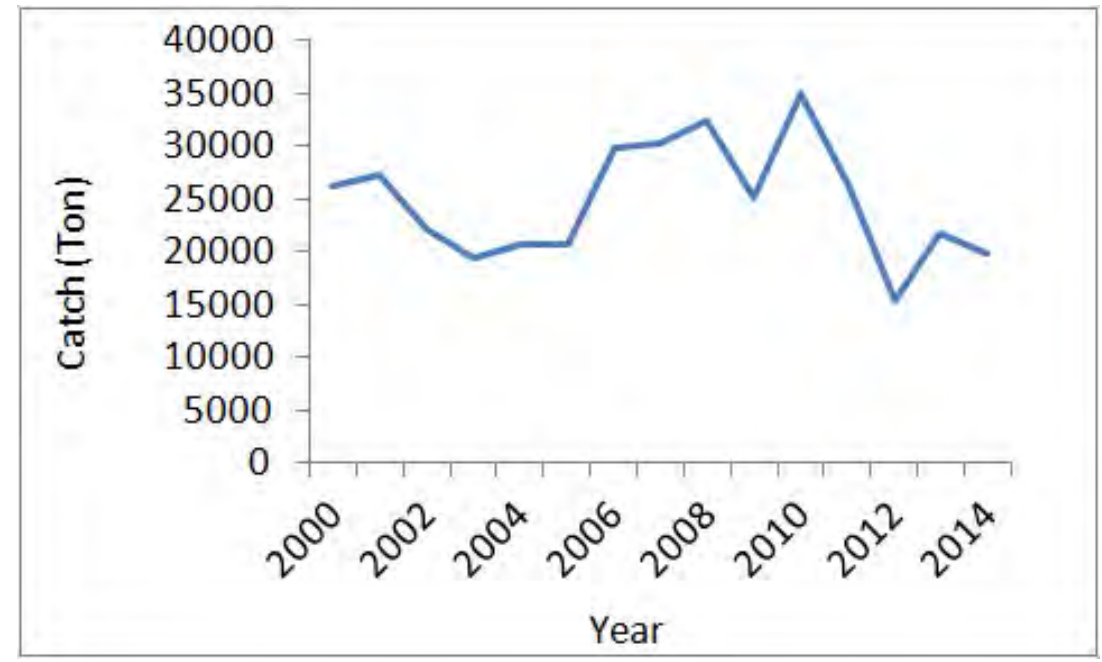

Figure 4 - Time series plot of the total annual (January-December) artisanal catches, by the beach seine, observed in Sofala Bank, during the period 2000 to 2014.

Figura 4 - Serie temporal das capturas artesanais totais anuais (Janeiro-Dezembro), capturadas por rede de arrasto à praia, no Banco de Sofala, durante o período de 2000 a 2014.

Table 2 - Dominant fish families caught by artisanal fisheries in Sofala Bank, using beach seine, during the period $2000-2014$.

Tabela 2 - Famílias das espécies dominantes nas capturas dos pescadores artesanais no Banco de Sofala, capturadas por rede de arrasto à praia, durante o período 2000-2014.

\begin{tabular}{ccc}
\hline Family & Total catch (Tons)(2000-2014) & Percentage (\%) \\
\hline Engraulidae & 167,144 & 53 \\
Clupeídea & 31,537 & 10 \\
Sciaenidae & 25,229 & 8 \\
Sergestidae (shrimp) & 22,076 & 7 \\
Trichiuridae & 18,922 & 6 \\
Ariidae & 12,615 & 4 \\
Penaeidae (shrimp) & 12,615 & 4 \\
Carangidae & 12,615 & 4 \\
Hemulidae & 6,307 & 2 \\
Ambassidae & 3,154 & 1 \\
Others & 6,307 & 2 \\
\hline
\end{tabular}

peídea with $10 \%$, Sciaenidae $(8 \%)$, shrimp of family Sergestidae (7\%), Trichiuridae (6\%), Ariidae (4\%) Penaeidae (4\%), Carangidae (4\%), Hemulidae (2\%), Ambassidae (1\%) and non identified species $(2 \%)$.

Figure 5 presents the time series plot of the total annual (January-December) artisanal catch by beach seine and the Zambezi River runoff, the total annual, the wet and the dry season, and the respective linear regression analysis. The best correlation was observed between the total annual (January-December) catches with the total annual (October-September) Zambezi River runoff (slope $=0.343, \mathrm{r}^{2}=0.500, \mathrm{p}=0.005, \mathrm{n}=14$ ), followed by the correlation of the catch with the wet season (October-Mar) Zambezi runoff (slope $=0.534, \mathrm{r}^{2}=0.369$, $\mathrm{p}=0.021, \mathrm{n}=14)$. There was also a good correlation between the catch and the dry season (May-August) runoff (slope $=0.773, \mathrm{r}^{2}=0.389, \mathrm{p}=0.013, \mathrm{n}=15$ ). Stepwise regression analysis showed that any of the data sets, namely, total annual, wet season and dry season runoff can be used, as all are correlated. Even the dry and wet season runoff are correlated $\left(\mathrm{r}^{2}=0.339\right.$, $\mathrm{p}=0.029$ ), probably due to river regulation. Thus, the best linear regression equation predicting the total annual (January-December) catch (tons) as a function of the total annual (October-September) Zambezi River runoff $\left(\mathrm{Mm}^{3}\right)$ is as follows:

$$
\text { Catch }=0.343 * \text { Runoff }+2255.4
$$

The entire coastal waters of Sofala Bank is dominated by freshwater (Figure 2), mostly from Zambezi River 


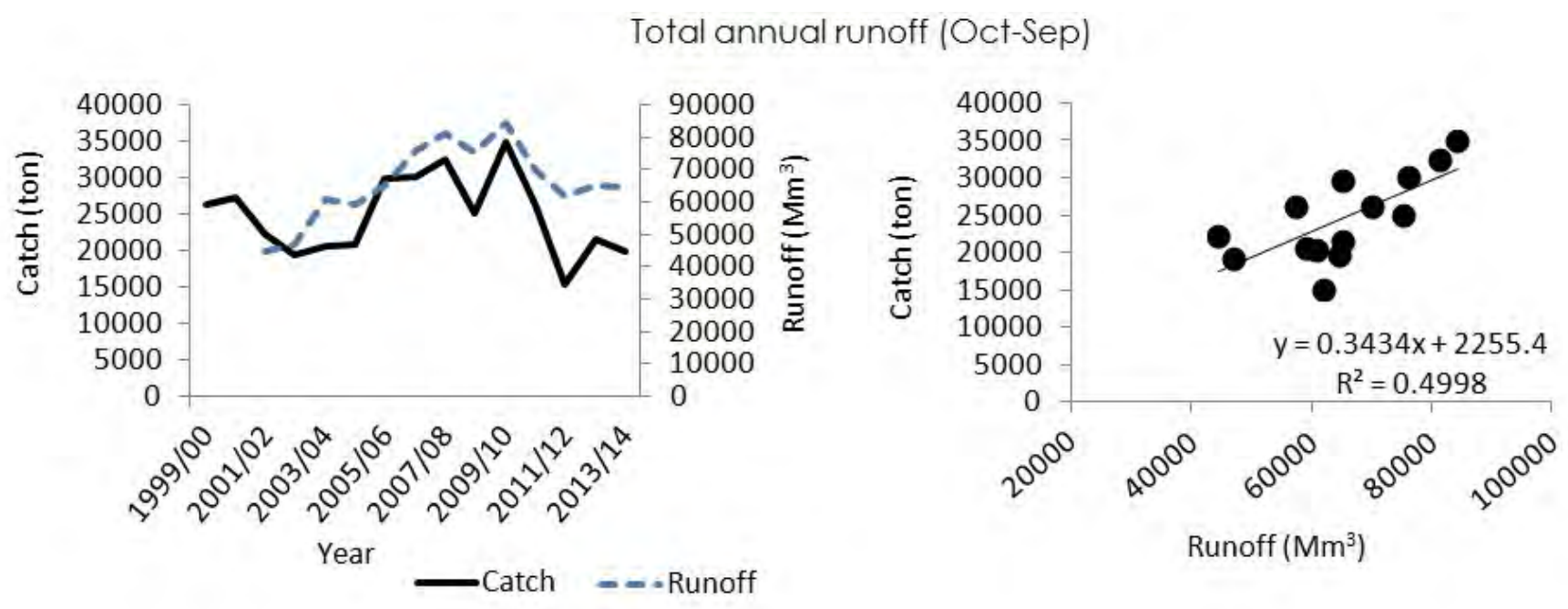

Wet season runoff (Sep-Mar)

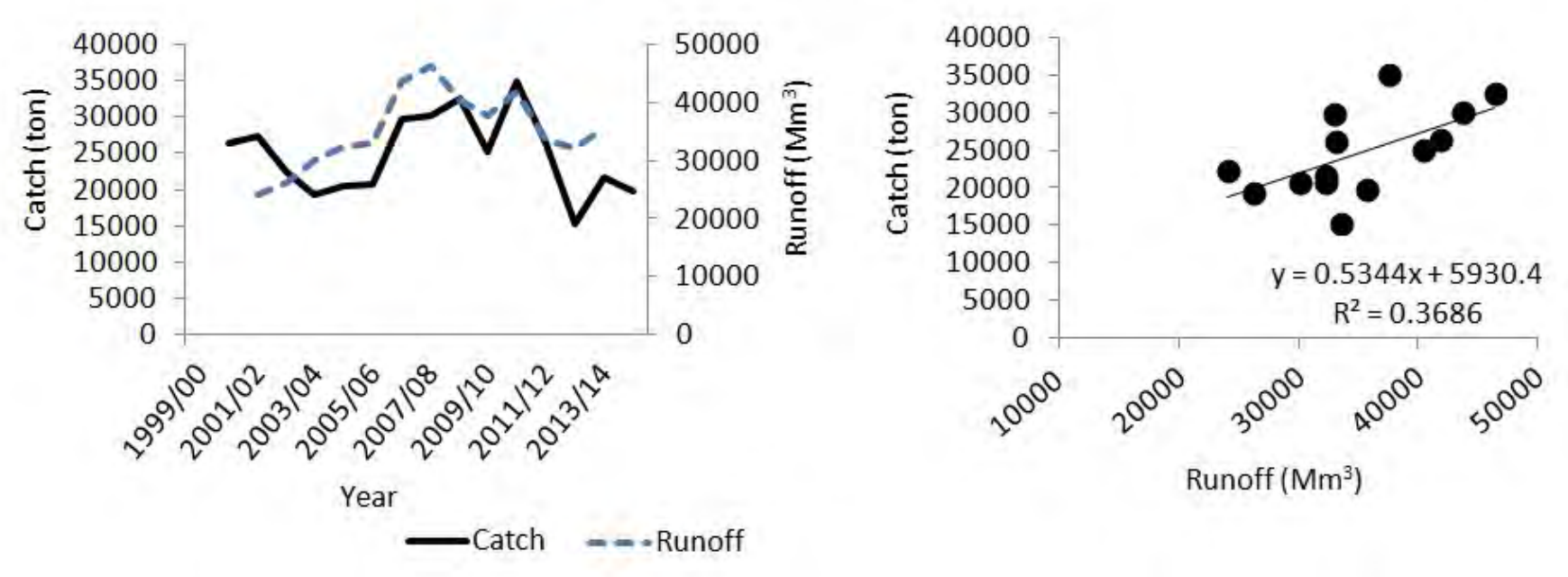

Dry season runoff (May-Aug)
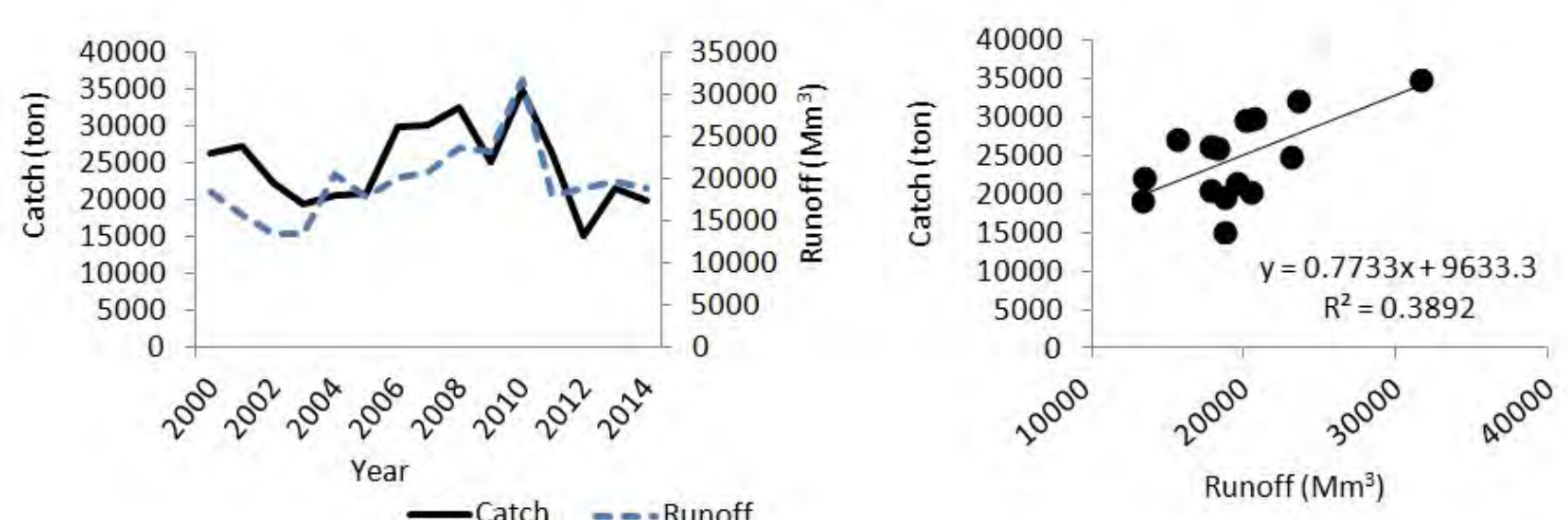

Figure 5 - Regression analysis of the annual artisanal catches (2000-2014) in Sofala Bank and the total annual Zambezi River runoff (1999/00-2010/14). .

Figura 5 - Resultados de regressão entre as capturas artesanais anuais (2000-2014) no Banco de Sofala e o escoamento anual do Rio Zambezi (1999/00-2010/14). 
(Siddorn at al. 2001; Steen \& Hoguane,1990; Sætre \& Silva 1984; Nehama\& Reason (in press)). Hence, the artisanal catches in Sofala Bank are dominated by estuarine species with the Engraulidae species totalling more than $50 \%$ of the catch. The species from this family spawn at the shelf, in marine environment, and the eggs and larvae development occur in estuaries and mangrove creeks environment, with suitable shelter against predators and with abundant food (Hoguane et al., 2012; Ayub, 2010; Loneragan, 1999). The Clupeidae, the second abundant species, were represented mostly by species of sardines and hilsa, which tolerate low saline waters, and sometimes enter in the river for spawning and feeding (Nelson, 1998; Froese \& Pauly, 2000). The species of shrimp Sergestidae, represented by species of genera Acetes and the shrimp of family Penaidae live in coastal waters during their adult stage, but the larval and juvenile phases are spent in estuaries and mangrove creeks (Simões et al., 2013). The species of the family Sciaenidae are benthic species that inhabit both the freshwater as well as the marine environments (Johnson \& Gill, 1998; Cisneros-Mata et al., 1994). Lastly, the species of the families Trichiuridae and Carangidae inhabit marine environment, from the shelf break up to interface with estuarine environment, thus, their presence in the artisanal catches could be explained by temporary immigration into the region of freshwater influence for feeding.

The positive correlation between the Zambezi river runoff and the artisanal catches in Sofala Bank reiterates the importance of the Zambezi on coastal ecosystems, despite the regulation. This result found in this study falls in line with several studies in other places of the world with similar characteristics, as follows: Loneragan (1999) studied the effect of the runoff of the Logan River in southeast Queensland, Australia, and confirmed that high river discharge can have a strong positive effect on the production of commercial and recreational coastal fisheries. Binet et al. (1994) studied the influence of the Congo River runoff and the coastal ecosystems and found a positive correlation between the runoff and the catches of Pseudotolithus elongates. Gammelsrød (1992) found a positive correlation between the Zambezi runoff and the catches of Penaeidae shrimp in Sofala Bank.

The rational of the positive relationship between the river runoff and the coastal fisheries production reside in two major arguments: firstly, the provision of nutrients through the river runoff which fertilises the coastal waters, boosting the phytoplankton production as explained by several authors (Gammelsrød, 1992, Meynecke et al. 2006 and Ayub, 2010) and secondly, the turbidity associated with river runoff creates a suitable sheltering environment against predators which in turn increases the survival rate of the larvae and juveniles, as explained by several authors (Hoguane et al., 2012;
Ayub, 2010; Loneragan, 1999). The good correlation between the wet season runoff and the catches could, in the similar way, be justified by the provision of food and shelter for juvenile brought by the freshwater from the river. However, the good positive relationship between the dry season runoff and the catches seems contradicting the argument that the river runoff should display a seasonal cycle, with high values during the wet season and low values during the dry season, to comply with ecosystems' seasonal dynamics as pointed out by several authors. Gammelsrød (1992) stated that the river flow regime in a regulated river should follow a natural pattern as much as possibly, i.e. with higher runoff during the wet season and low runoff during the dry season as to tune with the natural ecological cycles; and further stated that high runoff during the dry season may have a negative impact on the ecosystems health. Loneragan (1999) showed that the seasonal pattern of flow is equally important as the flow magnitude. Similar result was found by other authors (Binet et al., 1994).

While the river runoff regime is equally important as the runoff intensity, it should be emphasized, however, that the inflow of freshwater, both during the dry or wet season, supplies nutrients that fertilize the coastal water, providing food for fish. This would benefit all the species that spend their entire life in coastal waters or feed in these areas, regardless the season. Thus, the higher and the longer the freshwater supply the higher the primary production in coastal waters and the better for fish production. On the other hand, the dry season runoffs are likely to impact negatively the species which in the course of their life cycle would shift between estuaries and coastal waters, according to the river regime, as the penaeid shrimp studied by Gammelsrød (1992), which spawn in coastal waters and the development of the larvae and juveniles occurs in the sheltered estuarine and mangrove environments, then, the river regime should favour immigration of larvae, as passive drifters, from coastal water to estuaries and mangrove creeks, hence low flows, and conversely a flushing mechanism, through high flow, would be required to trigger the migration out the estuaries to fishing grounds. On the other hand, for those coastal species which do not undergo such migration, a continuous supply of nutrients by the river throughout the year would be beneficial. Similar result was found by Hossain et al. (2012) who studying the Fish diversity in Meghna river estuary reiterated the importance the estuaries as a suitable for spawning, development and growth of some species during their early life stage; Ramos et al. (2005) on studying fish larvae dynamics in the Lima River estuary reiterated the influence of the hydrodynamics on estuarine ichthyoplankton and, consequently, on the recruitment of marine coastal fish populations; Bardin \& Pont (2002) studying the environmental factors controlling 
the fish immigration in estuarine draining into Mediterranean sea, where the most dominant species were $\mathrm{Po}$ matoschistus spp., specie whose larvae and juvenile grow in estuaries, found that the availability of fish were mostly influenced by hydrographic conditions, mostly determined by river flow. Similar result was found by Dolbeth et al. (2007).

Correlation between the catches and the river runoff successively lagged by 1,2 and 3 years (not shown), were performed, but the lagged correlations were always poorer than the non-lagged. The best correlation in the present study between the total annual (JanuaryDecember) catches and annual (October-September) Zambezi Runoff, with no lag, is justified by the fact that most of the species of the catch Engraulidae, Sergestidae and Penaeidae, contributing with about $64 \%$ of the catch have a short time life cycle, from one to two years (Johnson \& Gill, 1998; Cisneros-Mata et al., 1994), and recruited to fishing area within their first year of life.

Based on the regression analysis and taking advantage of the fact that the Zambezi River is regulated; the fish production in Sofala Bank could be enhanced by adequately tuning the dam for desired downstream runoff. Intuitively, higher runoff throughout the year may give a wrong impression that fish production would increase. Righteously, that would not be the case since the species that requires immigration to the estuaries during their earlier stage of life would require a pronounced seasonal river flow regime to flourish. Hence, the present study reiterate the need for a reduction in the river runoff during the dry season, to boost successful immigration of fish eggs and larvae to the sheltered estuarine and mangrove environments and an increase in river runoff during the wet season to stimulate the migration of juveniles to the coastal fishing grounds, as suggested by Gammelsrød (1992). For instance, a reduction in $25 \%$ of river runoff during the dry season, and a consequent re-allocation of the same amount during the wet season, may result in an increase of about $12 \%$ in the annual catch.

\section{Concluding remarks}

The species composition of the artisanal catches in Sofala Bank is dominated by estuarine species and those species living in the adjoining seas and that feed in estuarine environment. The artisanal catches are positively correlated with the Zambezi River runoff, and the runoff explains the variability of catches by $50 \%$. The findings in this study reiterate the importance of the river runoff in the productivity of coastal ecosystems and, in particular, in fisheries production, hence, the call for the inclusion of the climate factors in fisheries management measures. Since the Zambezi River is regulated, fish production can be enhanced by managing the dams as to allow for increased flow, during the wet season and reduced flow, during the dry season.

\section{Acknowledgements}

We are grateful to Professor Tor Gammelsrød, from the Institute of Geophysics, University of Bergen, Norway, David A. Milton and two blind reviewers for the valuable constructive remarks and suggestions, which significantly improved the manuscript. The research was partial funded by NOMA (Norwegian Masters Programme), project number NOMAPRO-2007/10049, on Applied Marine Sciences for Sustainable Management of Natural Resources in Mozambique.

\section{References}

Arceo, Ayub, Z. (2010) - Effect of Temperature and Rainfall as a Component of Climate Change on Fish and Shrimp Catch in Pakistan. The Journal of Transdisciplinary Environmental Studies (ISSN: 1602-2297), 9(1):1-9, Roskilde, Denmark. Available on-line at http://www.journaltes.dk/vol_9_no_1_page_15/no\%203\%20\%20Edinger\%20og\%20Marti n $\% 20 \% 28$ high $\% 29$.pdf.

Bardin, O.; Pont, D. (2002) - Environmental factors controlling the spring immigration of two estuarine fishes Atherinaboyeri and Pomatoschistus spp. into a Mediterranean lagoon. Journal of Fish Biology, 61(3):560-578. DOI: 10.1111/j.10958649.2002.tb00896.x.

Binet, D.; Le Reste, L.; Diouf, P.S. (1994) - The influence of runoff and fluvial outflow on the ecosystems and living resources of West African coastal waters. In: Effects of Riverine Inputs on Coastal Ecosystems and Fisheries Resources, pp. 89-118, FAO Fisheries Technical Paper No.349, FAO - Food and Agriculture Organization of the United Nations, Rome, Italy. ISBN: 9789251036341. Available on-line http://www.fao.org/docrep/003/v4890e/V4890E04.htm\#ch4.

Cisneros-Mata, M. A.; Montemayor-Lopez, G.; Roman-Rodriguez, M.J. (1994) - Life history and conservation of Totoabamacdonaldi. Conservation Biology, 9(4):806-814. DOI: 10.1046/j.15231739.1995.09040806.x.

Conway, D.; Allison, E.; Felstead, R.; Goulden, M. (2005) - Rainfall variability in East Africa: implications for natural resources management and livelihoods. Philosophical Transactions of the Royal Society, A363:49-54. DOI: 10.1098/rsta.2004.1475.

Dolbeth, M.; Martinho, F.; Leitão, R.; Cabral, H.; Pardal, M.A. (2007) - Strategies of Pomatoschistus minutus and Pomatoschistus microps to cope with environmental instability. Estuarine, Coastal and Shelf Science, 74(1-2):263-273. DOI: 10.1016/j.ecss.2007.04.016.

Froese, R.; Pauly, D. (eds.) (2000) - FishBase 2000: concepts, design and data sources. 344p., ICLARM, Los Baños, Laguna, Philippines. ISBN 971-971-8709-99-1.

Gammelsrød, T. (1992) - Variation in shrimp abundance on the Sofala Bank, Mozambique, and its relation to the Zambezi River runoff. Estuarine, Coastal and Shelf Science, 35(1):91-103. DOI: 10.1016/S0272-7714(05)80058-7.

Garcia, S.M.; Zerbi, A.; Aliaume, C.; Do Chi; T.'Lasserre, G. (2003) - The ecosystem approach to fisheries. In: terminology, principles, institutional foundations, implementation and outlook. 71p., FAO Fisheries Technical Paper No.443, FAO - Food and Agriculture Organization of the United Nations, Rome, Italy. ISBN: 9251049602. Available on-line at http://ocean.floridamarine.org/efh_coral/pdfs/Ecosystem_Approaches_t o_Fisheries_FAO.pdf.

Hoguane, A.M.; Cuamba, E.L.; Gammelsrød, T. (2012) - Influence of rainfall on tropical coastal artisanal fisheries - a case study of Northern Mozambique. Journal of Integrated Coastal Zone Management / Revista de Gestão Costeira Integrada, 12(4):477482. DOI: $10.5894 /$ rgci338.

Hoguane, A.M.; Motta, H.; Lopes, S.; Menete, Z. (2002) - Mozambique National Report on integrated problem analysis - Devel- 
opment and protection of the coastal and marine environment in sub-Saharan Africa. 125p, GEF MSP Sub-Saharan Africa Project (GF/6010-0016), Maputo, Mozambique. Unpublished.

Hossain, M.S.; Das, N.G.; Sarker, S.; Rahaman, M.Z. (2012) - Fish diversity and habitat relationship with environmental variables at Meghna river estuary, Bangladesh. The Egyptian Journal of Aquatic Research, 38(3):213-226. DOI: 10.1016/j.ejar.2012.12.006.

Instituto nacional de Investigação Pesqueira (2007-2011) - Relatórios anuais de 2007 a 2011. Instituto Nacional de Investigação Pesqueira, Maputo, Moçambique. In: www.moziip.org.

Jacquet, J.L.; Zeller, D. (2007) - National conflict and fisheries: Reconstructing marine fisheries catches for Mozambique. In: D. Zeller \& D. Pauly (eds.), Reconstruction of marine fisheries catches for key countries and regions (1950-2005). Fisheries Centre Research Reports (ISSN: 1198-6727) 15(2):35-47, Fisheries Centre, University of British Columbia, Vancouver, Canada. Available on-line: http://www.seaaroundus.org/researcher/dpauly/PDF/2007/Books\&Chapt ers/.

Johnson, G.D.; Gill, A.C. (1998) - Perches and their allies. In: J. R. Paxton \& W. N. Eschmeyer (eds.), Encyclopedia of Fishes. 2nd ed., pp.181-194, Academic Press, San Diego, CA, USA. ISBN: 978-0125476652.

Larkin, P.A. (1996) - Concepts and issues in marine ecosystem management. Reviews in Fish Biology and Fisheries, 6(2):139164. DOI: 10.1007/BF00182341.

Loneragan, N.R. (1999) - River flows and estuarine ecosystems: Implications for coastal fisheries from a review and a case study of the Logan River, southeast Queensland. Australian Journal of Ecology, 24:431-440. DOI: 10.1046/j.1442-9993.1999.00975.x.
Meynecke, J.-O.; Lee, S.Y.; Duke, N.C.; Warnken, J. (2006) - Effect of rainfall as a component of climate change on estuarine fish production in Queensland, Australia. Estuarine, Coastal and Shelf Science, 69(3-4):491-504. DOI: 10.1016/j.ecss.2006.05.011.

Nehama, F.P.J.; Reason, C.J.C. (in press) - Morphology of the Zambezi River plume in the Sofala Bank, Mozambique. Western Indian Ocean Journal of Marine Sciences, in press.

Nelson, G. (1998) - Clupeidae: Wikis. In: J. R. Paxton \& W. N. Eschmeyer (eds.), Encyclopedia of Fishes. 2nd ed., pp.91-92. Academic Press, San Diego, CA, USA. ISBN 0125476655.

Ramos, S.; Cowen, R.K.; Paris, C.; Ré, P.; Bordalo, A.A. (2005) Environmental forcing and larval fish assemblage dynamics in the Lima River estuary (northwest Portugal). Journal of Plankton Research, 28(3):275-286. DOI: 10.1093/plankt/fbi104.

Sætre, R.; Jorge da Silva, A. (1984) - The Circulation of the Mozambique Channel. Deep-Sea Research, 31(5):485-508. DOI: 10.1016/0198-0149(84)90098-0.

Siddorn, J.R.; Bowers, D.G.; Hoguane, A.M. (2001) - Detecting the Zambezi River Plume Using Observed Optical Properties. Marine Pollution Bulletin, 42:942-950. DOI: 10.1016/S0025326X(01)00053-4.

Simões, S.M.; D’Incao, F.; Fransozo, A.; Castilho, A.L.; da Costa, R.C. (2013) - Sex ratio, growth and recruitment of the pelagic shrimp Acetesamericanus on the southeastern coast of Brazil. Journal of Crustacean Biology (E-ISSN: 1937-240X), 33(1):19. DOI: 10.1163/1937240X-00002108; ISSN: 0278-0372.

Steen, J.-E. And Hoguane, A.M. (1990) - Oceanographic results on expedition carried out by $R / V$ Dr. Fridjof Nansen in Mozambique waters during April-May 1990. 35p., Relatório No. 13. Maputo, Mozambique. Unpublished. 